\title{
SUSTAINABILITY ASSESSMENT OF AGRICULTURAL PRODUCTION: CASE STUDY OF LATVIAN CROP SECTOR
}

\author{
Arnis Lenerts ${ }^{1}$, Dina Popluga ${ }^{2}$, Rogier P.O. Schulte ${ }^{2,1}$, Irina Pilvere ${ }^{1}$ \\ ${ }^{1}$ Latvia University of Agriculture, Latvia; ${ }^{2}$ Wageningen University, Netherlands \\ arnis.lenerts@1lu.lv, dina.popluga@1lu.lv
}

\begin{abstract}
The concept of sustainability in agricultural production is characterised by three interrelated dimensions: environmental sustainability; economic sustainability; and social sustainability. Research studies are needed to understand what the specific characteristics of each dimension are and how they interact in time and space. The aim of this research is to make a sustainability assessment of agricultural production in the crop sector in Latvia. In the paper, the authors have compiled existing studies that have tried to include all the three dimensions of sustainability analysis and to provide explanations of factors determining sustainable agricultural production. It was concluded that some agricultural development indicators pointed to the challenges of meeting sustainable economic development objectives in agricultural production. The results showed that this development of agricultural production in the crop sector took place at the expense of natural capital impairment, as the environmental sustainability index had fallen from a neutral value of 0 to a negative value of -0.25 during the last decade. Activity data characterising the production practices of crop farms pointed to a non-sustainable farming system, where the intensity of exploitation of production resources of fossil origin had essentially increased.
\end{abstract}

Keywords: sustainability, assessment, crop, production.

\section{Introduction}

Agriculture and its specific form of production is a unique part of the single economic, environmental and social system. The key and basic purpose and objective of agriculture is to produce food for humans. An analysis of achieving this objective in global context done by the authors showed that the situation in all regions of the world is not homogenous. At the beginning of the industrial era in around the 1790s, there were approximately 800 million people that had to be supplied with food. Today, the total world population exceeds 7 billion, and it is expected that food will be needed for about 9.3 billion by 2050 [1;2].

In developed countries, achieving quantitative targets in food production for consumption has not been a priority since the 1970s; however, with the world population increasing as well as with the purchasing power of the population rising, the demand for food is projected to increase $[1 ; 2]$. Even though population growth rates are not equal across the world's regions, resources needed for meeting the growing demand and providing the entire world population with food are constrained. Supplying 7 billion people with food has estimated to require: a third of dry-land agro-ecosystems, approximately half of fresh water resources as well as a double amount of nitrogen and phosphorous naturally present in the environment [3]. Accelerated global economic growth has led agriculture to commence a complicated development cycle, as the demand for food has to be met by observing the principle of sustainability - beginning with the production cycle through to processing and distribution to final consumers [4]. The entire food supply chain - production, processing and distribution - has to be sustainable, and a number of assessment and calculation methods are employed to examine it.

The most popular methods in analyses of sustainable development are as follows: life cycle assessment, cost-benefit analysis, environmental impact assessment and ecosystem valuation. Sustainable production standards, principles and criteria are developed employing the mentioned methods. These methods usually employ the same input data, yet the applications of the data can considerably differ [5].

Selecting a set of accurate indicators for assessing sustainable development is a complicated task, as the indicators have to reflect correct changes in the interrelated systems of all sustainability dimensions. The aim of this research is to assess sustainability of crop production. In order to achieve the aim and determine the situation in such complicate system as the crop sector an indicator method was used where any selected indicator meets certain criteria showing changes in a system. 


\section{Materials and methods}

The authors have used the publications and studies of foreign and Latvian scientists, reports and statistical data from Farm Accountancy Data Network (FADN) and Central Statistical Bureau of Latvia (CSB). The studies all applied accepted research methods in economics, i.e. monographic descriptive method, analysis and synthesis methods, as well as strong focus on the development of an approach for assessing sustainability in agriculture, which is described further.

Various research papers suggest diverse sets of indicators for assessing sustainability in agriculture. A research study on theoretical possibilities for assessing the sustainable intensification of agricultural systems found that up to 500 various indicators were suggested for sustainable intensification assessment. Of the indicators, 202 could be characterised as relating to social dimensions, 95 - to economic dimensions and 198 related to environmental assessment. Only the remaining five indicators might be considered to be ones showing other changes [6]. At present, a number of sets of indicators have been created and exist, which are employed as those measuring sustainability. A few of overall indicator systems are as follows: Eurostat Sustainable Development Indicators [7]; 17 Sustainable Development Goals [8]; OECD Agri-environmental Indicators [9]; OECD Green Growth Indicators [10]; OECD Better Life Index [11]; OECD Well-being indicators [12]; Environmental Performance Index (EPI) [13]; Ecological Footprint [14]; Living Planet Index (LPI) [15]. However, indicator systems that are suitable for measuring sustainability at farm level can be mentioned the following: Sustainability indicators for the Farm Accountancy Data Network (FADN) network [16]; Indicators of sustainability at farm level by dimension of [17].

Based on an analysis of such information, the authors believe that targets and a set of indicators have to be defined for agricultural development in Latvia, which would be consistent with the marginal values of natural, financial, human and manufactured capital. At national macroeconomic level, a combined, synthetic indicator or an index that would best show changes in capital of each type exploited in production has to be used to assess sustainable intensification in agriculture. An assessment of sustainable intensification in crop farming is performed employing a four-step methodology: (1) identification and definition of causes of an activity; (2) definition of appropriate sustainability indicators; (3) definition of sustainable intensification indexes; (4) identification of effects on sustainable development. Based on the definition of sustainable agricultural intensification, the authors have assumed what the dynamics of change in the indicators of each type of capital should be. The basic idea of sustainable agricultural intensification is to increase the productivity of land resources, while enhancing environmental management. There are three types of expression of sustainable intensification: "soft" sustainable intensification where the environmental impacts increase at a rate that is lower than the increase in well-being/ economic activity; "medium" sustainable intensification where the environmental impact is kept stable in the face of growing economic activity/ well-being (e.g., the case of Irish milk production, which is growing, and GHG emissions, which are flat-lining); "hard" sustainable intensification where the environmental impacts decrease at the rate that is equal or faster than the increase in well-being/ economic activity.

This means that a combination of the factors of production exploited in agricultural production is not the same for all agricultural management systems and industries, therefore unified and comparable indicators for assessing diverse systems have to be defined to assess sustainable agricultural development. The indicators showing change in the value of capital have to be: appropriate, reliable, accurate, comparable, and easy to interpret and based on good quality/ credible input data. The process of selection and calculation of indicators is presented in Figure 2. In selecting an indicator, one can use: direct output data (e.g. GHG emissions from crop farming); a ratio or a coefficient (e.g., the share of GHG emissions from crop farming in total agricultural emissions); a relative indicator (e.g., GHG emissions per $\mathrm{kg}$ protein or per $\mathrm{kJ}$ food).

According to the scientific literature, the key causal relationships of activities in crop farming that affect sustainable intensification are as follows:

- economic: profitability; diversification of economic activity; financial and resource autonomy; stability of economic activity;

- social: working and living conditions on agricultural holdings; application of best farming practices; production of socially responsible products; 
- environmental: fertilisers and plant protection products applied; agricultural land tillage; renewable energy sources; agricultural land quality control; biodiversity, GHG emissions;

- technological/ innovation: change of technological processes and equipment; development of products; learning.

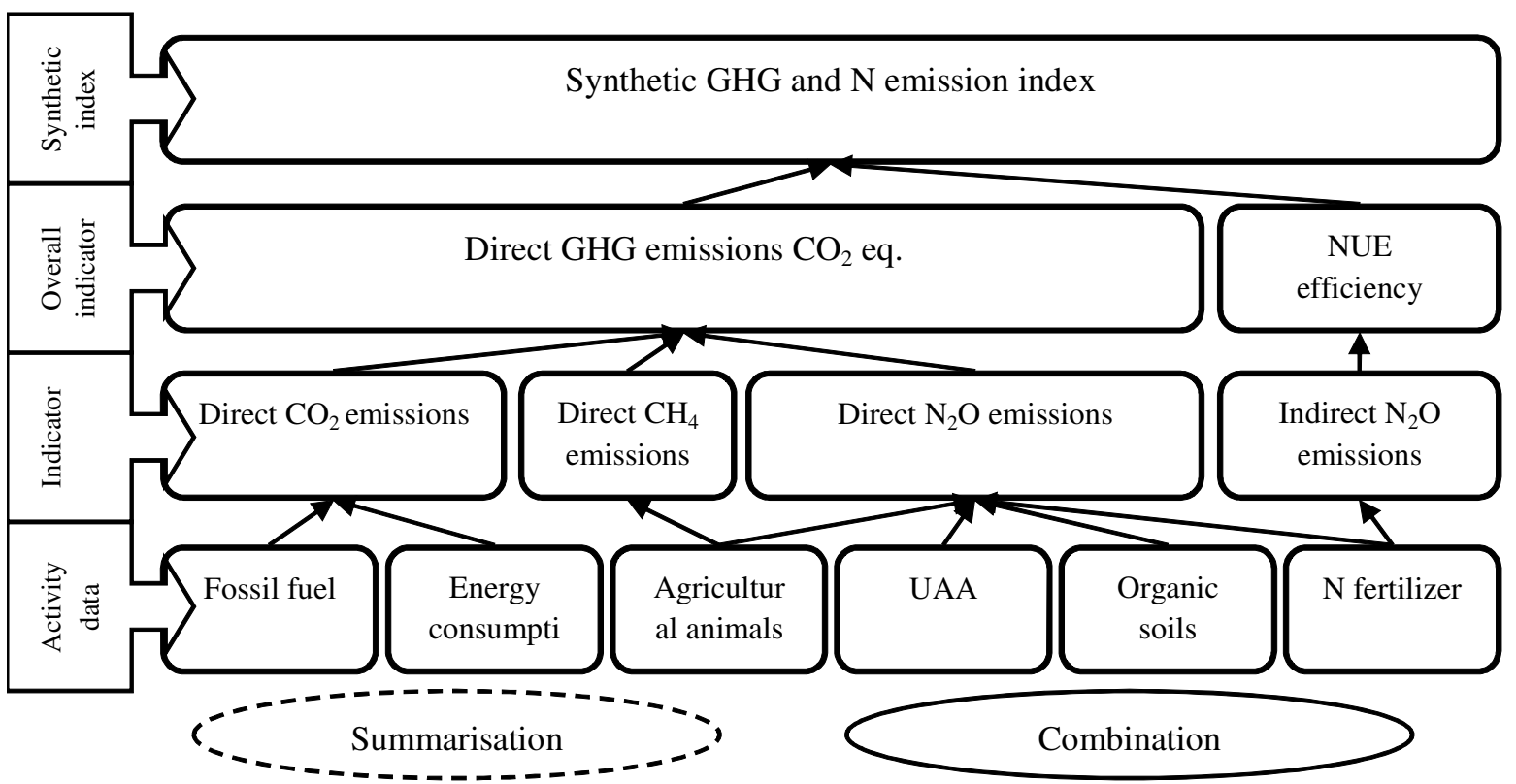

Source: authors' construction

Fig. 1. Example of sequential selection and calculation of indicators for assessment of sustainable agricultural intensification

\section{Results and discussion}

Sustainable agricultural intensification in Latvia has to be socially just and ecologically and economically viable, achieving the objective of producing sustainable agricultural produce. In view of the global context of production of agricultural products, the agriculture of Latvia has to be ready for new challenges, considering the products produced in the context of sustainability. It is necessary to assess agricultural production by sustainability category in order to adapt it for sustainable development [18]. According to the research aim set, the assessment of sustainable intensification in crop farming basically involves the identification of changes in indicators and of measures to be introduced by agricultural holdings to ensure their development is sustainable. By employing the assessment method developed, it is possible, for example, to identify indicator values after GHG emission reduction measures have been introduced in agriculture, compared with the situation if no such measures are implemented. The assessment of sustainable agricultural intensification integrates all the sustainability dimensions, and present and future benefits are identified at farm microeconomic level [19]. The authors, selecting the best indicators, defined six key necessary characteristics of sustainable development:

- change in development have to be a positive value oriented towards the future;

- all the key sustainable intensification factors are assessed and their interrelations are analysed;

- interdependence of economic, social, environmental and technological/innovation factors is determined;

- compromises among the factors are minimalized;

- factor effectiveness is assessed taking into account human needs for sustainability;

- methodology for assessment is simple and comprehensible for all stakeholders involved. 
Initially, the selection of indicators for each group of sustainability factors was based on research studies available in the scientific literature. For performing the selection, summarisation, calculation and interpretation of indicators at farm level, a number of methods have been suggested: RISE [20]; SAFE [21]; MOTIFS [22]; SOSTARE [23], as well as a method suggested by M.N. Thieverges [24]. Of all the examined theoretical methods for analysing indicators, the authors chose the method for assessment of agricultural and environmental sustainability developed by Van Cauwenbergh, which involves performing an assessment at four levels, and its sequence is presented in Table 1. A unified list of the most necessary indicators appropriate for the conditions in Latvia was developed according to the above-mentioned characteristics of sustainable development. A methodology ,Sustainability Indicators: Measuring the Immeasurable?" developed by S. Bell and S. Morse [25] as well as a research study on sustainability assessment by employing FADN indicators conducted in the EU Member States [16] were used when assessing the appropriateness of every indicator.

Table 1

Levels for assessment of agricultural sustainability

\begin{tabular}{|c|c|c|c|}
\hline $\begin{array}{l}\text { Change } \\
\text { in } \\
\text { capital }\end{array}$ & $\begin{array}{l}\text { Factor's function } \\
\text { for change in } \\
\text { capital }\end{array}$ & Criterion & Indicator \\
\hline \multirow{4}{*}{ 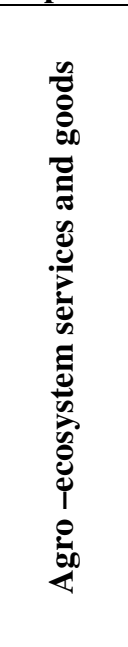 } & $\begin{array}{l}\text { Economic } \\
\text { function }\end{array}$ & $\begin{array}{l}\text { Farm revenue; reduced dependence on } \\
\text { support payments; reduced agricultural } \\
\text { production risks. }\end{array}$ & $\begin{array}{c}\text { Revenue from agricultural } \\
\text { produce; agriculture as a } \% \text { of } \\
\text { GDP; insured UAA. }\end{array}$ \\
\hline & Social function & $\begin{array}{c}\text { Enhancement of work conditions; provision } \\
\text { of jobs in rural areas; generational continuity } \\
\text { on farms; farm revenue from non- } \\
\text { agricultural activities }\end{array}$ & $\begin{array}{l}\text { Employment in agriculture; } \\
\text { risk to abandon agricultural } \\
\text { activity; economic dependence } \\
\text { on primary agricultural } \\
\text { production. }\end{array}$ \\
\hline & $\begin{array}{l}\text { Environmental } \\
\text { function }\end{array}$ & $\begin{array}{l}\text { Preservation of biodiversity; soil quality } \\
\text { maintenance; reduction of emissions into the } \\
\text { environment; optimisation of use of fossil } \\
\text { energy resources; maintenance of biotope } \\
\text { diversity. }\end{array}$ & $\begin{array}{l}\text { Farm type; crop rotation in the } \\
\text { UAA; N application balance; } \\
\text { plant protection products; } \\
\text { energy consumption balance. }\end{array}$ \\
\hline & $\begin{array}{l}\text { Innovation/ } \\
\text { technological } \\
\text { function }\end{array}$ & $\begin{array}{l}\text { Agricultural production; production } \\
\text { technology exploited; build-up of new } \\
\text { knowledge. }\end{array}$ & $\begin{array}{l}\text { Investment in new machinery; } \\
\text { the area under papilionaceous } \\
\text { plants; agricultural processing. }\end{array}$ \\
\hline
\end{tabular}

Source: authors' construction based on [21]

Using the system of levels for assessment of indicators, change in the values of the agroecosystem services and goods created by all the types of capital is assumed to be the starting point. Certain criteria, from which indicators are derived and which influence a function, are set for any change in capital of each type at the next level.

The list contained 44 indicators that were appropriate for sustainability criteria assessment. The purpose of the assessment was to identify sustainable agricultural intensification at farm-level; therefore, the next step performed in the selection of indicators involved examining potential databases. There were two alternatives in the acquisition of data - to use the data of the FADN or the CSB. Both databases were representative; the indicators were regularly updated and statistically credible. The data grouped by farm economic size and by farm type in the FADN database were more consistent with the research task. Some data were acquired from the CSB and national inventory reports (NIR), and the authors did necessary indicator calculations. The number of indicators needed for the assessment of development had to be reduced, which considerably simplified the interpretation of results. The number of indicators was reduced by performing a correlation analysis between the indicators of one group, and an indicator was excluded from the list if its correlation coefficient was higher than 0.9 and it represented an identical causal relationship in the factor group. After the assessment was completed, the final list of indicators for the factors of sustainable intensification consisted of: five indicators for the economic factors, five for the social factors, five for the environmental factors and five indicators for the technological/innovation factors. Table 2 presents the indicators for each factor group and the development trajectory of every indicator. 
Indicators for the factors of sustainability for crop farms in Latvia

\begin{tabular}{|c|c|c|c|c|c|}
\hline \multicolumn{2}{|c|}{$\begin{array}{l}\text { Indicator } \\
\text { code }\end{array}$} & \multirow{2}{*}{$\begin{array}{c}\text { Indicator } \\
\text { UAA productivity }\end{array}$} & \multirow[t]{2}{*}{ Parameter } & \multirow{2}{*}{$\begin{array}{c}\begin{array}{c}\text { Measurement } \\
\text { unit }\end{array} \\
\text { EUR } \cdot \mathrm{ha}^{-1}\end{array}$} & \multirow{2}{*}{$\begin{array}{c}\text { Change } \\
\text { (个 increased; } \\
\rightarrow \text { doesn't } \\
\text { changed; } \\
\downarrow \text { decreased) } \\
\uparrow\end{array}$} \\
\hline \multirow{5}{*}{ 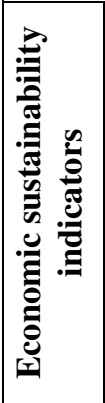 } & EK 4 & & & & \\
\hline & EK 7 & $\begin{array}{l}\text { Diversification of } \\
\text { economic activity }\end{array}$ & $\begin{array}{c}\text { Proportion of the area } \\
\text { under wheat and rapeseed }\end{array}$ & $\%$ & $\downarrow$ \\
\hline & EK 9 & Labour productivity & $\begin{array}{l}\text { Crop output per employee } \\
\text { in crop farming }\end{array}$ & $\begin{array}{l}\text { EUR per } \\
\text { employee }\end{array}$ & $\uparrow$ \\
\hline & $\begin{array}{c}\text { EK } \\
10\end{array}$ & $\begin{array}{c}\text { Financial stability of an } \\
\text { enterprise }\end{array}$ & $\begin{array}{c}\text { Support payments as a \% } \\
\text { of total revenue }\end{array}$ & $\%$ & $\downarrow$ \\
\hline & $\begin{array}{c}\text { EK } \\
12\end{array}$ & Utilised agricultural area & $\begin{array}{l}\text { Unfarmed agricultural } \\
\text { area as a } \% \text { of the total }\end{array}$ & $\%$ & $\downarrow$ \\
\hline \multirow{5}{*}{ 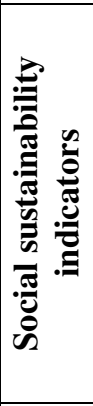 } & SO 5 & $\begin{array}{l}\text { Retention of jobs in } \\
\text { rural areas }\end{array}$ & $\begin{array}{c}\text { Full-time employees per } \\
100 \text { ha of UAA }\end{array}$ & $\begin{array}{l}\text { employees per } \\
100 \text { ha }\end{array}$ & $\uparrow$ \\
\hline & SO 6 & $\begin{array}{c}\text { Creation of jobs in rural } \\
\text { areas }\end{array}$ & $\begin{array}{l}\text { Proportion of revenue } \\
\text { from agricultural }\end{array}$ & $\%$ & $\uparrow$ \\
\hline & SO 9 & $\begin{array}{c}\text { Social responsibility of } \\
\text { an enterprise }\end{array}$ & $\begin{array}{c}\text { Proportion of social } \\
\text { security contributions in }\end{array}$ & $\begin{array}{l}\text { EUR per } \\
\text { employee }\end{array}$ & $\rightarrow$ \\
\hline & $\begin{array}{l}\mathrm{SO} \\
12 \\
\end{array}$ & Social exclusion risk & $\begin{array}{l}\text { Ratio of the unemployed } \\
\text { to the employed in rural }\end{array}$ & $\%$ & $\rightarrow$ \\
\hline & $\begin{array}{c}\mathrm{SO} \\
13 \\
\end{array}$ & Employment & $\begin{array}{c}\text { Number of agricultural } \\
\text { employees }\end{array}$ & $\%$ & $\rightarrow$ \\
\hline \multirow{5}{*}{ 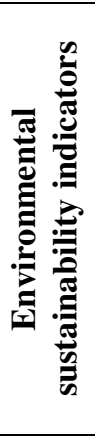 } & VI 1 & $\begin{array}{l}\text { Emission intensity in the } \\
\text { agro - ecosystem }\end{array}$ & $\begin{array}{l}\text { Fertilisers consumed in } \\
\text { crop farming per ha }\end{array}$ & EUR $\cdot \mathrm{ha}^{-1}$ & $\downarrow$ \\
\hline & VI 2 & $\begin{array}{l}\text { GHG emissions in crop } \\
\text { farming }\end{array}$ & $\begin{array}{l}\mathrm{N}_{2} \mathrm{O}, \mathrm{CH}_{4} \text { and } \mathrm{CO}_{2} \text { direct } \\
\text { emissions from the UAA } \\
\text { into the environment }\end{array}$ & $\mathrm{Gg}$ & $\rightarrow$ \\
\hline & VI 6 & $\begin{array}{l}\text { Environment-friendly } \\
\text { management system }\end{array}$ & $\begin{array}{c}\text { Proportion of the } \\
\text { organically farmed area in }\end{array}$ & $\%$ & $\uparrow$ \\
\hline & VI 9 & Soil enhancement & $\begin{array}{l}\text { Application of manure in } \\
\text { crop farming }\end{array}$ & $\mathrm{t} \cdot \mathrm{ha}^{-1}$ & $\uparrow$ \\
\hline & $\begin{array}{l}\text { VI } \\
10 \\
\end{array}$ & $\begin{array}{c}\text { Preservation of } \\
\text { biodiversity }\end{array}$ & $\begin{array}{l}\text { Application of plant } \\
\text { protection products in }\end{array}$ & EUR $\cdot$ ha $^{-1}$ & $\downarrow$ \\
\hline \multirow{5}{*}{ 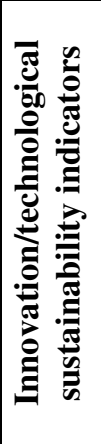 } & TI 1 & $\begin{array}{l}\text { Development of crop } \\
\text { products }\end{array}$ & $\begin{array}{l}\text { Proportion of the area } \\
\text { under papilionaceous } \\
\text { plants in the total UAA }\end{array}$ & $\%$ & $\uparrow$ \\
\hline & TI 2 & $\begin{array}{c}\text { Development of crop } \\
\text { processing }\end{array}$ & $\begin{array}{l}\text { Proportion of expense on } \\
\text { crop processing in the }\end{array}$ & $\%$ & $\uparrow$ \\
\hline & TI 3 & $\begin{array}{c}\text { Innovations in } \\
\text { production technologies }\end{array}$ & $\begin{array}{l}\text { Proportion of expense on } \\
\text { machinery purchase in the }\end{array}$ & $\%$ & $\rightarrow$ \\
\hline & TI 4 & $\begin{array}{c}\text { Innovations in the } \\
\text { system of production }\end{array}$ & $\begin{array}{c}\text { Farm-produced manure } \\
\text { per ha of UAA }\end{array}$ & EUR $\cdot \mathrm{ha}^{-1}$ & $\uparrow$ \\
\hline & TI 5 & $\begin{array}{c}\text { Innovations in } \\
\text { production processes }\end{array}$ & $\begin{array}{c}\text { Farm-produced seed per } \\
\text { ha of UAA }\end{array}$ & EUR $\cdot \mathrm{ha}^{-1}$ & $\rightarrow$ \\
\hline
\end{tabular}

Source: authors' construction

The factor indicators acquired have to be assessed at the next stage of development of the indicator system in order to identify their relative weight of importance. Each indicator was sequentially compared with the others. Using Formula 1, the importance or relative weight was calculated for each indicator:

$$
S_{i}=\frac{p_{\max }-p_{i}+1}{\sum_{i=1}^{n} p_{i}},
$$


where $S_{i}$ - weight of $i$-th indicator,

$P_{i}$ - number of advantages for $i$-th indicator.

The weight for the number of advantages for each indicator shows the relative weight of its importance in the range from 0 to 1 . Then the relative weight of each factor's importance was calculated according to the equation. The calculated weights of the indicators of sustainable intensification in crop farming are summarised in Table 3.

Table 3

Indicator weights for the factors of sustainability for crop farms in Latvia

\begin{tabular}{|c|l|c|}
\hline $\begin{array}{c}\text { Indicator } \\
\text { code }\end{array}$ & \multicolumn{1}{|c|}{ Indicator } & $\begin{array}{c}\text { Calculated indicator } \\
\text { weight } \boldsymbol{S}_{\boldsymbol{i}}\end{array}$ \\
\hline EK 4 & UAA productivity & 0.08 \\
\hline EK 7 & Diversification of economic activity & 0.06 \\
\hline EK 9 & Labour productivity & 0.07 \\
\hline EK 10 & Financial stability of an enterprise & 0.08 \\
\hline SO 5 & Retention of jobs in rural areas & 0.06 \\
\hline SO 6 & Creation of jobs in rural areas & 0.03 \\
\hline SO 9 & Social responsibility of an enterprise & 0.10 \\
\hline VI 1 & Emission intensity in the agro - ecosystem & 0.10 \\
\hline VI 10 & Preservation of biodiversity & 0.10 \\
\hline VI 6 & Environment-friendly management system & 0.04 \\
\hline TI 1 & Development of crop products & 0.10 \\
\hline TI 3 & Innovations in production technologies & 0.10 \\
\hline TI 4 & Innovations in the system of production & 0.08 \\
\hline & & Total \\
\hline
\end{tabular}

Source: authors' construction

In the next step, the indicators were normalised, the key purpose of which was to make the indicator values comparable, as the range of the factor values was very broad and they were expressed in incomparable units of measurement. Owing to normalisation, the initial units of measurement disappear and the diverse indicators become mutually comparable. The normalised indicator values for the factors of sustainable intensification in crop farming, $R_{i}$, were calculated for six farm groups of various economic sizes, which represented 347 agricultural holdings that specialised in field crops.

The sustainable intensification development index, IA, was calculated by Formula 2. There were used the weights for each factor indicator and the normalised values of each indicator calculated earlier. To perform a comparison, the development index was calculated for every economic size group using the data for 2005 and 2015.

$$
I A_{i}^{\prime}=\sum_{i=1}^{n} S_{i} R_{i g},
$$

where $I A_{i}-$ sustainable intensification development index for the $i$-th farm group,

$S_{i}$ - weight for $i$-th sustainability indicator,

$R_{i g}$ - value of $i$-th normalised indicator for the $g$-th farm group.

In the calculations of the IA index, the indicator values were summed according to the trajectory defined in Table 2. If an indicator has to increase in value, the plus (+) sign is used, whereas if the indicator has to decrease the minus (-) sign is used. The IA indexes calculated for crop farms and broken down by group of economic, social, environmental and innovation/technological factors are presented in Figure 2.

The data analysed show differences in development among the farm groups of various economic sizes. The group of large farms has intensified the agricultural production process, yet the impact on the environment has increased. With the economic processes continuing in rural areas that result in increases in the physical size (managed UAA) and the economic size, the impact on the rural environmental is going to increase, which contradicts the principles of sustainable development. 


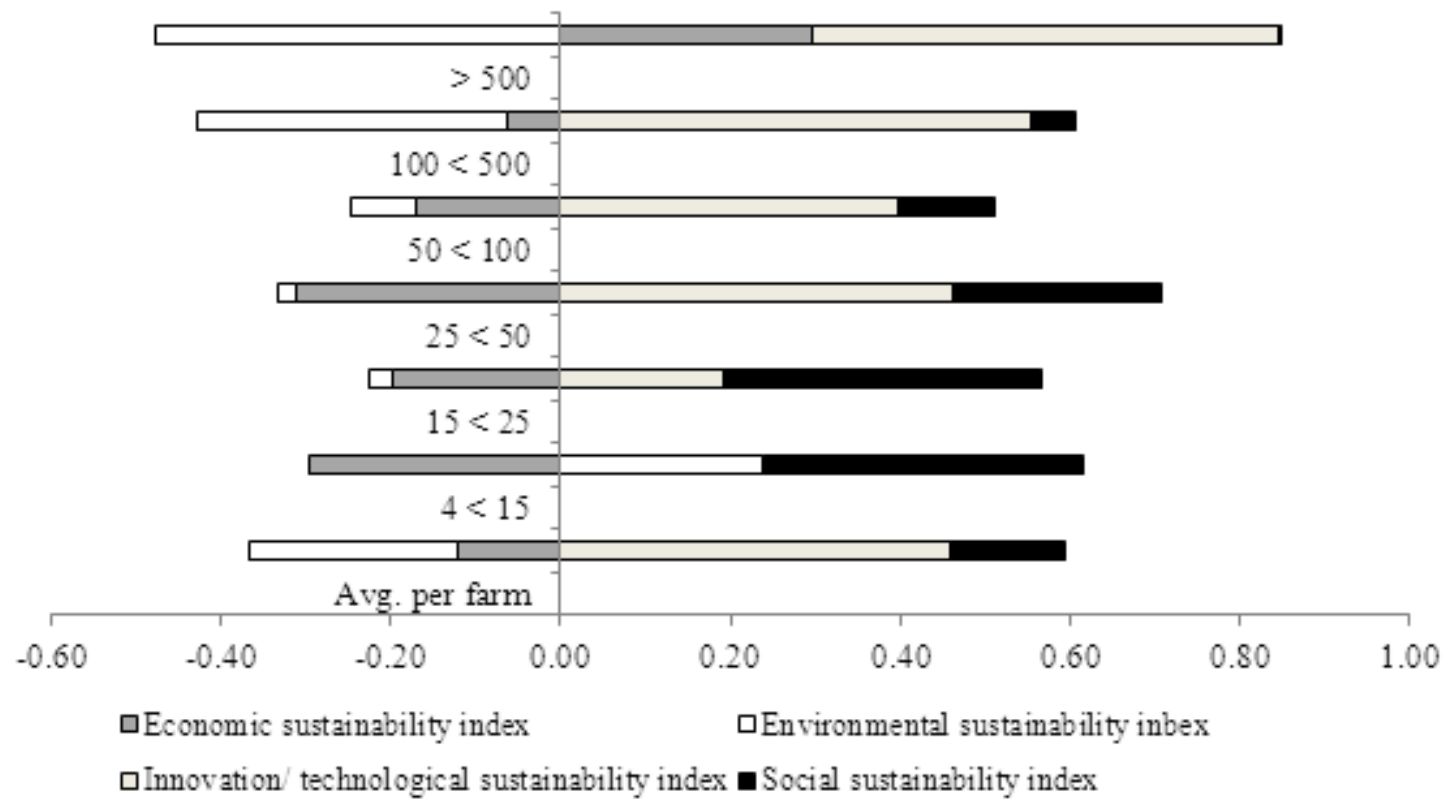

Source: authors' calculations after FADN data

Fig. 2. Sustainable intensification development index for crop farms representing different economic sizes (thsd. EUR) in Latvia, 2015

\section{Conclusions}

1. Sustainability assessment of crop sector has showed that in 2015 average Latvian crop farm meets innovation and social sustainability, which means that such indicators as - retention of jobs, creation of jobs in rural areas, social responsibility of an enterprise, development of crop products, innovations in production technologies and in the system of production - shows positive changes; however negative values of economic and environmental sustainability indexes point to the challenges of meeting overall sustainability, where special focus should be paid on UAA productivity, diversification of economic activity, labour productivity, financial stability of an enterprise, emission intensity and environment-friendly management system, preservation of biodiversity.

2. The results showed that there can be found considerable differences in development and meeting certain aspects of sustainability among the farm groups of various economic sizes:

- the main challenge for farms with economic size ranging from 4 till 50 thsd. EUR per year is meeting economic sustainability. Currently theses farms meet insufficient profitability, lack diversification of economic activities and financial and resource autonomy, as well show instability of their economic activity;

- the main challenge for farms with economic size over 500 thsd. EUR per year is meeting environmental sustainability. Study results showed that within group of these farms exploitation of production resources of fossil origin had essentially increased (mainly due to constantly increasing amount of fertilisers and plant protection products applied; and agricultural land tillage practice). In order to meet environmental sustainability more focus should be paid on usage of renewable energy sources, agricultural land quality control, biodiversity, GHG emissions.

\section{Acknowledgements}

This research was carried out with generous funding by the Government of Latvia within the National Research Programme 2014-2017 project "Value of the Latvia's ecosystem and climate dynamic impact on those - EVIDEnT" sub-project 3.2. "Analysis of GHG emissions from agricultural sector and economic assessment of GHG emissions mitigation measures" (No. 2014/VPP2014-2017). 


\section{References}

1. Tilman D., Fargione J.,Wolff B., D'Antonio C., Dobson A., Howarth R., Schindler D., Schlesinger W.H., Simberloff D., Swackhamer D. Forecasting agriculturally driven global environmental change. Science, vol. 292, 2001, pp. 281-284.

2. Alexandratos N., Bruinsma J. World agriculture towards 2030/2050: the 2012 revision. ESA Working paper No. 12-03. Rome, FAO, 2012. [online] [22.02.2017] Available: http://www.fao.org/docrep/016/ap106e/ap106e.pdf

3. Vitousek P.M., Mooney H.A., Lubchenco J., Melillo J.M. Human domination of earth's ecosystems. Science, vol. 277, issue 5325, 1997, pp. 494-499.

4. Charles H., Godfray H.C., Beddington J.R., Crute I.R., Haddad L., Lawrence D., Muir J.F., Pretty J., Robinson S., Thomas S.M., Toulmin C. Food security: the challenge of feeding 9 billion people. Science 327, (2010) 812-818.

5. Bartelmus P. Quantitative Eco-nomics. How sustainable are our economies? Springer Science and Business Media B.V, 2008, 329 p.

6. Buckwell A., Heissenhuber A., Blum W. Sustainable intensification of european agriculture. Centre for European Policy Studies, 2014. [online] [24.02.2017] Available: http://www.risefoundation.eu/images/files/2014/2014_\%20SI_RISE_FULL_EN.pdf

7. Sustainable development in the European Union. [online] [24.02.2017] Available: $\mathrm{http} / / /$ ec.europa.eu/eurostat/documents/3217494/6987735/KS-GU-15-001-EN-N.pdf/425b049bcc3d-447b-84d7-0d06a39c261f

8. Indicators of Sustainable Development: Guidelines and Methodologies. [online] [20.02.2017] Available: http://www.un.org/esa/sustdev/natlinfo/indicators/guidelines.pdf

9. Agri - Environmental Indicators for Agriculture. [online] [21.02.2017] Available: http://www.oecd.org/agriculture/sustainable-agriculture/agri-environmentalindicators.htm

10. Towards Green Growth: Monitoring Progress. OECD Indicators. [online] [20.02.2017] Available: http://www.oecd.org/greengrowth/48224574.pdf

11. OECD Better Life Index. [online] [20.02.2017] Available: http://www.oecdbetterlifeindex.org/\#/11111111111

12. Compendium of OECD well-being indicators. [online] [20.02.2017] Available: http://www.oecd.org/general/compendiumofoecdwell-beingindicators.htm

13. Environmental Performance Index. JRC Analysis and Recommendations, 2014. [online] [20.02.2017] Available: http://archive.epi.yale.edu/

14. Working Guidebook to the National Footprint Accounts. [online] [20.02.2017] Available: http://www.footprintnetwork.org/images/article_uploads/NFA \%202014 \%20Guidebook \%20714-14.pdf

15. Living Planet Report. WWF International, 2014. [online] [23.02.2017] Available: http://wwf.panda.org/about_our_earth/all_publications/living_planet_report/

16. Poppe K., Vrolijk H., Dolman M., Silvis H. FLINT - Farm-level Indicators for New Topics in policy evaluation: an introduction. Studies in Agricultural Economics, vol. 118, No. 3, 2016, pp. 116-122.

17. Herrera B., Gerster-Bentaya M., Knierim A. Stakeholders' perceptions of sustainability measurement at farm level. Studies in Agricultural Economics, vol. 118, 2016, pp. 131-137.

18. Pope J., Bond A., Morrison-Saunders A., Retief F. Advancing the theory and practice of impact assessment: setting the research agenda. Environmental Impact Assessment Review, vol. 41, 2013, pp. 1-9.

19. Bond A., Morrison-Saunders A., Pope J. Sustainability assessment: the state of the art. Impact Assessment and Project Appraisal, vol. 30:1, 2012, pp. 53-62.

20. Häni F., Braga F., Stämpfli A., Keller T., Fisher M., Porche H. RISE, a tool for holistic sustainability assessment at the farm level. International food and agribusiness management review, vol. 6(4), 2003, pp. 78-90.

21. Van Cauwenbergh N., Biala K., Bielders C., Brouckaert V., Franchois L., Cidad V.G., Hermy M., Mathijs E., Muys B., Reijnders J., Sauvenier X., Valckx J., Vanclooster M., der Veken B.V., Wauters E., Peeters A. SAFE - a hierarchical framework for assessing the sustainability of agricultural systems. Agricultural Ecosystems Environment, vol. 120, 2007, pp. 229-242. 
22. Meul M., Van Passel S., Nevens F., Dessein J., Rogge E., Mulier A., Van Hauwermeiren A. MOTIFS: a monitoring tool for the integrated farm sustainability. Agronomy for sustainable development, vol. 28, 2008, pp. 321-332.

23. Paracchini M.L., Bulgheroni C., Borreani G., Tabacco E., Banterle A., Bertoni D., Rossi G., Parolo G., Origgi R., De Paola C. A diagnostic system to assess sustainability at a farm level: The SOSTARE model. Agricultural Systems, vol. 133, 2015, pp. 35-53.

24. Thivierge M.N., Parent D., Bélanger V., Angers D.A., Allard G., Pellerin D., Vanasse, A. Environmental sustainability indicators for cash-crop farms in Quebec, Canada: a participatory approach. Ecological indicators, vol. 45, 2014, pp. 677-686.

25. Bell S., Morse S. (2008) Sustainability indicators: Measuring the immeasurable? London: Earthscan, $251 \mathrm{p}$. 